\title{
Az egészségturizmus értelmezése a turizmus változó rendszerében
}

\author{
Szerzők: Ruszinkó Ádám¹ - Donka Attila²
}

A totális turizmus idōszakában egyre szélesedik a termékpaletta, és az egyes termékeken belül egyre sokszinübbé és specializáltabbá válnak a szolgáltatások. Olyan új vagy eddig csak részben érintett szakterületek is markánsabb szerepet kapnak, amelyeknek eredendóen csekély kapcsolódásuk volt a turizmushoz. Egyúttal felértékelődött az egészség, az utazási motivációk között hangsúlyosabb szerepet kap annak megôrzése, vagy a visszaszerzésére való törekvés. Ezáltal folyamatosan nô az egészségturisztikai szolgáltatásokat igénybe vevők száma. Mindez azzal jár, hogy olyan területeken is megjelent a turizmus, amelyek kívül esnek a korábban elfogadott fogalmi rendszeren. A cikk igyekszik tisztázni a fogalomrendszer pontatlanságait, illetve korrigálni a vonatkozó definíciókat.

Kulcsszavak: egészségturizmus, wellnessturizmus, gyógyturizmus, orvosi turizmus, fogalomrendszer.

\section{Bevezetés}

Számos szerző tett már kísérletet az egészségturizmust, illetve az ahhoz kapcsolódó területeket érintő fogalmak meghatározására (VAJDA-VADAS 1990, RÁTZ 2001, HEGEDÜS 2006, AMBRUS 2006, ROZSNYAI 2006, FÓRIS-BÉRCZES 2006, PRISZINGER-PÉNZES 2009, SMITH-PUCZKÓ 2008, KINCSES et al. 2009, SZIVA 2010, MEZŐKOVÁCS 2010, FENYVESI 2010, DOBAZSIGMOND 2013, EGÉSZSÉGTUDOMÁNYI FOGALOMTÁR). A kísérletek egy része közvetlenül kapcsolódott különböző témájú kutatásokhoz, módszertani alapot teremtve számukra. Ezekben az esetekben rendszerint nem törekedtek a teljességre a fogalmak széles körét illetően. Voltak olyan megközelítések is, amelyek kifejezetten a fogalomrendszer alkalmazásának sokszínûségét igyekeztek bemutatni, célként fogalmazva meg bizonyos alapvető kifejezések definiálását is.

Az egyes tudományterületek vagy részterületek, amelyeknek - viszonylag rövidebb időre viszszatekintô múltjuk miatt - még nem alakult ki a tudományban (és a szakmai körökben) közmegegyezéssel elfogadott módon definiált fogalomrendszere, igénylik az egységes megközelítést. Az egészségturizmus a kezdeti időket már meghaladta a fogalmak megalkotása terén is, ezért kialakulóban van egy viszonylag azonos értelme-

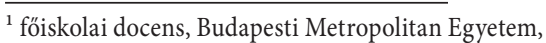

adam.ruszinko@gmail.com

${ }^{2}$ főiskolai tanársegéd, Kodolányi János Egyetem, donkaoktatas@gmail.com
}

zés az egyes kifejezéseket illetően. Ám ez a viszonylagosság, valamint a totális turizmus révén kiszélesedő szakterületek éppen elegendőek ahhoz, hogy a gazdasági életben (tehát a turizmus múködése, múködtetése közben), de ugyanúgy az oktatásban is félreértések és félreértelmezések keletkezzenek, amelyek aztán jogi, pénzügyi, vagy más negatív következményekkel járhatnak. Ezért szükséges, hogy az előzményekre tekintettel, de a trendeket, az érintett szakmák meghatározásait és az érvényben lévő jogszabályokat sokkal inkább figyelembe véve, megalapozottan és hosszú távra szólóan megszülessen a mindenki számára érthető és használható fogalmak rendszere az egészségturizmus egyre bóvülő területén.

\section{Az egészségturizmus jelentôsége}

Az egyes fogalmak mögötti tartalom érvekkel alátámasztott pontosítása előtt szükség van a jelen helyzet ismertetésére, majd ezt továbbgondolva egy mindenki által elfogadhatónak és alkalmazhatónak tartott, szükség esetén kibővített fogalmi definíciórendszerre tett javaslat kidolgozására. Jelen esetben ez azért fontos, mert az egészségturizmus két olyan tudomány által megalapozott terület, amelyek egyike, az egészségtudomány tekintettel arra, hogy a lehetó leginkább gyakorlatias, egyúttal az emberek fizikai teljességét tûzte ki célként - talán más területeknél is fokozottabban igényli, sőt, megköveteli a lehető legpontosabb fogalmakat a gyógyítás vagy az egészségmegőrzés sikeressége érdekében.

A tudományok oldaláról az egészségturizmusban rejlő kettősséget talán úgy lehet a legegyszerúbben kifejezni, hogy az egészségtudomány el- 
sősorban az ember (a beteg, a turista, a vendég), tehát a kereslet oldaláról vesz részt benne, míg a gazdaságtudomány (MICHALKÓ-RÁTZ 2003) a kereslet és a kínálat felől egyaránt közel teljes körú vizsgálatra törekszik. A turizmustudomány - a gazdaságtudományok részeként - feladatai közé tartozik, hogy mind a vendégeket fogadók oldaláról (fogadóterület részei, gazdálkodó szervezetek, intézmények, közösségek), mind az annak gazdasági előnyöket jelentő, tehát vendégforgalmat (kereslet) generáló szempontból vizsgálja az egészségturizmust.

\subsection{AZ EGÉSZSÉGTURIZMUS KERESLETE}

Az egészségturizmus iránt nemcsak hazánkban, hanem nemzetközi szinten is nő a kereslet, melyet számos tényező generál (RÁTZ-MICHALKÓ 2011). Annak ellenére, hogy a különböző stratégiákban, koncepciókban az egészségturizmus és az életminőség kapcsolata ritkán jelenik meg (GONDOS 2012), a jövőben még inkább szükséges volna hangsúlyozni az egészséges életmód és a gyógyfürdő-igénybevétel közötti szoros összefüggést (SZABÓ 2011). A világgazdaság jövője szempontjából az egészségüggyel kapcsolatos innovációkat alapvetô jelentôségúnek tartják. Egyre több iparág kerül kapcsolatba az egészségüggyel, a társadalmi trendhatások egyre inkább befolyásolják az emberek egészségmagatartását (MÁLOVICSMÁLOVICS 2009).

A hazai termál- és gyógyfürdők az elsó Széchenyi Tervnek (2000) és az azt követő EU-s forrásoknak köszönhetően 2012-re kétséget kizáróan a hazai egészségturizmus főszereplői lettek (a szállodai vendégéjszakák 33,7\%-át adták együttesen a gyógy- és wellness-szállodák).

\subsection{AZ EGÉSZSÉGTURIZMUS KÍNÁLATA}

A kínálat bővülése egyedülálló módon ment végbe, és zajlik napjainkban is. A wellness-szállodák számának növekedése elképesztő mértékú, miközben a gyógyhotelek száma sokéves, lassú növekedés után az elmúlt években enyhe visszaesést mutat. A jelen tanulmányban vizsgált probléma itt is tetten érhető, ugyanis ahogy a szállodák osztályba sorolását, úgy a gyógyszálloda minősítést is sok szolgáltató önkényesen, valódi mögöttes tartalom nélkül használja.

Hazánk egészségturizmusáról elmondható, hogy a turisztikai termék a legtöbb, komoly vendégforgalmú fürdővárosban megfelelően összeállt, azaz mind infrastrukturálisan (fürdő, szálloda, éttermek, üzletek, egyéb szolgáltatások, közlekedés), mind humán szempontból (felkészült szakembe- rek) kielégítő, sőt, sok helyen kifejezetten európai színvonalú. Néhány jellemző adat az egészségturizmus kínálatáról és keresletéról:

- 99 minősített gyógyfürdő van, 5 gyógybarlang és 2 településen van gyógygáz, illetve 5 hazai település rendelkezik minósített gyógyiszappal;

- az elismert gyógyvizek jegyzéke 270 különböző gyógyvizet tartalmaz;

- jelenleg 32 település rendelkezik gyógyhely minősítéssel (ebből 12 az elmúlt két év során szerezte meg a minősítést); ${ }^{3}$

- a 40 gyógyszállóban éves szinten 2,5 millió vendégéjszakát töltenek el a vendégek ${ }^{4}$;

- a gyógyfürdők látogatószáma tavaly meghaladta a 41 milliót ${ }^{5}$.

A nagy hagyományokkal bíró gyógyturizmus mint turisztikai termék, számos ponton különbözik a turizmus más termékeitől:

- hosszabb tartózkodási idó jellemzi, mert részben krónikus betegségek gyógykezeléséről van szó;

- pozitív élmények (például tartós tünetmentesség) esetén valószínúbb a vendégek viszszatérése;

- magasabb vendégköltés jellemzi, mely a szolgáltatások szélesebb körére irányul (a gyógyvendégek a hosszabb tartózkodás miatt számos, jellemzően a helyi lakosság által igénybe vett szolgáltatást is megvesznek);

- a meggyőzéséhez speciális marketingstratégia szükséges, egy „tudományosan megalapozott üzenet", melynek alapja a bizonyítékokon alapuló orvoslás, közismertebb angol nevén: evidence based medicine (RUSZINKÓDONKA 2015).

Az egészségturizmus múködésének komplexitására és a fejlődés sikertényezőinek sokrétûségére egyértelmúen utal az ORSZÁGOS EGÉSZSÉGTURIZMUS FEJLESZTÉSI STRATÉGIA (2007). Régóta ismert dolog, hogy a hazai fürdők, egészségturisztikai központok csak abban az esetben lehetnek sikeresek, ha megfelelően alkalmazkodva a piac igényeihez egy-egy jól körülhatárolt célcsoport igényeit maximálisan igyekeznek kiszolgálni (BUDAI-SZÉKÁCS 2001). Nem

\footnotetext{
${ }^{3}$ A természetes gyógytényezőkkel összefüggő minősítéseket és a nyilvántartások kezelését az Állami Népegészségügyi és Tisztiorvosi Szolgálat (ÁNTSZ) végzi. A nyilvános adatok naprakészen elérhetőek a szervezet honlapján (https://www.antsz.hu/).

${ }^{4} \mathrm{http}: / /$ magyarturisztikaiszovetseg.hu/wp-content/uploads/2018/07/ sajt\%C3\%B3anyagmeme.pdf

${ }^{5}$ https://turizmus.com/szabalyozas-orszagmarketing/megujul-a-furdok-vedjegyrendszere-1161138
} 
elhanyagolható az állandó versenyhelyzet sem. A turisztikai keresletet a '90-es évekig egyszerú motivációstruktúra jellemezte, csekély elvárásokkal. Napjainkban, illetve a jövőben azok a desztinációk tehetnek szert különleges piaci előnyökre, melyek széles és differenciált termékpalettával lépnek piacra (AUBERT-BERKI 2007).

A fogalmi keretek vizsgálatának aktualitását tehát az egészségturizmus dinamikus fejlődése és egyúttal nemzetgazdasági jelentősége adja. A szolgáltatók jelentős száma egyúttal nagyszámú munkavállalót jelent, akik folyamatosan növekvó számú vendégeket szolgálnak ki. Ennél fogva az egészségturizmus stratégiai termék is (NTS 2017).

\section{Problémafelvetés}

Jelen tanulmány célja az egészségturizmus területét érintő, pontatlanul használt vagy vitatott fogalmak tartalmi tisztázása. Ennek érdekében elsőként áttekintettük a fogalmi rendszer fejlődését.

Szükségesnek tartjuk felhívni a figyelmet arra, hogy az egészségturizmus körébe tartozó szolgáltatások jelentős része nemcsak a turisták, hanem a rekreációs céllal érkező helyi lakosság életminóségének javulásához is hozzájárul. Tekintettel azonban arra, hogy a turizmusból származó bevételek messze meghaladják a helyi lakosság ilyen irányú költéseit, nem tartjuk célravezetónek a vendégkör alapján külön kezelni az egyes fogalmakat. Ekképpen az általunk javasolt egységes fogalmi rendszer a turizmus általános rendszere alapján közelíti meg az egyes fogalmakat (például fogászat alatt fogászati turizmust értünk), és az egyes egészségturisztikai szolgáltatások mellett feltételezi a kínálati oldal további elemeinek a jelenlétét.

Bár sokan foglalkoztak a meghatározásokkal, pontos tartalmi fejlődés csak ritkán volt tapasztalható. Az újabb termékek, szolgáltatások megjelenése után egyáltalán nem, vagy pontatlanul, esetleg a korábbiaknak ellentmondóan, vagy csak lassan indult meg a hozzájuk tartozó fogalmak definiálása. Az egészségturizmus iránti kereslet gyors növekedésével a szerzók többnyire csak követő jelleggel törekedtek erre, illetve nem került sor olyan kutatásokra, amelyek egy felvázolt jövőkép alapján, az egészségturizmus egyre bővülő területén kialakuló (vagy már jelen lévô) egyes szolgáltatásokhoz kapcsolódó fogalmak széles körben elfogadható meghatározására tettek volna kísérletet. Így napjainkban erősen zavaros a kifejezések egy részének használata. Ezt csak fokozza, hogy egy-egy, a média által gyakran használt, népszerúvé váló kifejezést óhatatlanul szélesebb kör kezdi használni, minek következtében számos pontatlanság, félrevezetó megközelítés alakul ki ezen kifejezések körül. Ez különösen abban az esetben jellemzó, amikor a szolgáltató szektor szereplői piaci elónyöket remélve címkeként alkalmazzák, gyakran alaptalanul, félrevezetve ezáltal a vendégeket. Jellemzô például a wellness szó túlzott és gyakran pontatlan használata. Ezért tartjuk fontosnak, hogy elsődlegesen a szakmában, de emellett a tudományos életben és az oktatásban résztvevók, különösen ügyeljenek az egzakt szóhasználatra, a fogalmi rendszer pontos alkalmazására. A vizsgálatok során az alábbi problémák megoldására kerestük a válaszokat:

- Az egészségturizmus szolgáltatásainak, termékeinek rendszerezése nem megfelelő, a fő kategóriák - wellness, gyógy- és orvosi turizmus - lehatárolása ellentmondásos, sôt, az érvényben lévő jogszabályoknak sem felel meg.

- Számos olyan új termék jelent meg az egészségturizmus piacán, melyek fogalmi meghatározása még nem történt meg kellő alapossággal.

\section{Módszerek}

A fogalmi rendszer elemeinek meghatározására az egészségturisztikai ágazatban - különösen az elmúlt két évtizedben - végbement fejlődés vizsgálatával került sor. Ennek keretében igyekeztünk feltárni a turisztikai termékek kapcsolódásait, elsősorban az egészségügy vonatkozásában.

A kutatás során tanulmányoztuk a szakterület releváns fogalmainak az egészségturizmus alakulásával párhuzamos fejlódését. Ez kiterjedt egyrészt korábbi kutatási eredményeket ismertető múvek értékelésére, másrészt oktatási anyagok, valamint az érvényben lévő jogszabályok, illetve a szakmai közéletben, a szakmai szervezetek által, valamint a mindennapokban rendszeresen alkalmazott szóhasználat tanulmányozására. A jogszabályi környezet meglehetősen szerteágazó. A fogalmi rendszer egy része közvetlenül nem szabályozott, ám közvetve érintett. Ide tartoznak a statisztikai méréshez kapcsolódó fogalmi meghatározások, például a szállodakategóriák (a gyógyvagy a wellness-szálloda) definiálása. A direkt módon meghatározott fogalmak jelentőségüknél fogva a különbözó jogszabályokban kaptak helyet.

\subsection{KORÁBBI KÍSÉRLETEK A FOGALMAK MEGHATÁROZÁSÁRA}

Tanulmányunk arra tesz kísérletet, hogy rendszerbe foglalja egyrészt azokat a meglévô, elfogadott fogalmakat, amelyeket jogszabály vagy igen erős szakmai konszenzus határoz meg, másrészt azokat az újonnan kialakuló, szolgáltatásokhoz kapcsolódó fogalmakat, amelyek az egészségügyhöz 
vagy más ágazathoz való tartozásuk miatt más jelentéstartalommal jelennek meg az adott területen, például a turizmusban, az oktatásban vagy akár a médiában. Mivel azonban nem arról van szó, hogy forradalmian új kifejezéseket alkossunk, hosszú idótávot átfogóan kell megvizsgálnunk, mikor, hogyan jelent meg a fogalomkör vagy annak egyes részei a szakirodalomban. Jól láthatóan nem mutatható ki egyenletes fejlődés a fogalmak terén, szinte ahány szerző, annyiféle oldalról közelítették meg a feldolgozást. Ennek ellenére igyekeztünk rámutatni arra, hogy a korábbi kísérletek közül napjainkban mely elemek helytállóak, illetve a jelenlegi tendenciákat figyelembe véve várhatóan melyek maradnak helytállóak a jövőben is.

Ha rendszerbe akarjuk foglalni az egészségturizmussal kapcsolatos fogalmak szakirodalmi megjelenését, akkor elsődlegesen a jogszabályi környezetet kell alapul vennünk. Az elsó szerzők a 2000-es évek elején jelentek meg, majd a további kutatók egyre bővülő fogalommagyarázatokra tettek kísérletet. Ezt követően többen vizsgálták a fogalmak fejlődését, miközben a fogalmi keretrendszert több felsőoktatási tananyag is magáévá tette.

A természetes gyógytényezőkrôl szóló jogszabály ${ }^{6}$ számos fogalmat meghatároz. Ezek mindegyike részben vagy egészben turisztikai célra használt létesítmény (gyógyszálló, gyógyhely, gyógyfürdō, klimagyógyintézet, mozgásszervi betegeket ellátó nappali kórház, gyógyfürdőkórház, szanatórium, gyógyüdüló, gyógyvíz-ivócsarnok, gyógybarlang). A múltban tehát a fogalmak meghatározása elsődlegesen az egészségügy irányából, az egészségügyi szolgáltatások szempontjából történt meg, döntően a gyógyturisztikai szolgáltatások kapcsán. Ehhez a turizmus is igazodik, azzal a kitétellel, hogy a turizmusban ennél jóval szélesebb a meghatározandó fogalmak köre.

A fogalomkör a rendszerváltozás előtt jelentősen eltérő volt. Korábban termál- és gyógyturizmusnak hívták a terméket, melyet az aktív turizmushoz soroltak. A termálturizmus korai fogalma (VAJDA-VADAS 1990) nem rendszerszemléletúen került meghatározásra, illetve a gyógy-idegenforgalom sem szolgáltatásközpontú elemekkel került megtöltésre.

Az egészségturizmus és annak folyamatosan bővülő fogalomrendszere hosszú folyamat eredményeként alakult ki. Az első kísérletek az alapfogalmak meghatározására a 2000-es évek elején történtek a termék előtérbe kerülésével. Az első Széchenyi Terv (2000), illetve annak turizmusfejlesztési programjában található egészségturizmus alprogram, révén a fejlesztések új lendületet vet- tek. A főleg fürdō- és szálláshelyfejlesztések újfent megalapozták a hazai kínálat versenyképességét, míg ezzel párhuzamosan megindultak a fogalomalkotásra tett kísérletek is.

Az Állami Egészségügyi Ellátó Központon belül Kincses Gyula igyekezett megalkotni az alapvetô meghatározásokat (EGÉSZSÉGTUDOMÁNYI FOGALOMTÁR), döntôen az egészségügy oldaláról. Ennek keretében alakult ki az egészségturizmus, a gyógyturizmus és a medical wellness kifejezések definiálása, míg a wellnessturizmus csupán a rekreációs turizmus fogalmán belül került értelmezésre. Ennél már összetettebben, és a turisztikai szerepét alapul véve foglalkozott az egészségturizmussal RÁTZ (2001), a termékkel kapcsolatos új trendeket értékelő tanulmányában. A szerzó rendkívül óvatosan fogalmaz, megállapítja, hogy nincs még kialakult konszenzus a fogalom tartalmával kapcsolatban, egyúttal felhívja a figyelmet arra is, hogy jelentős különbségek vannak az egyes országokban használt elnevezéseket illetően. Ezek közül példaként a spa eltérő európai és észak-amerikai értelmezését mutatta be. Ennél fogva csak arra tett kísérletet, hogy ezen kitételekkel, általános értelemben határolja körül a termékkel kapcsolatos alapfogalmakat.

A forráskutatás során a jogszabályi környezet mellett alapvető múnek tekintettük AZ EGÉSZSÉGTURIZMUS MARKETINGKONCEPCIÓJÁT (2002), mint az egyik legelső olyan munkát, amely rendszerszerúen foglalkozik a terület múködésével, mind a gyógyászati, mind a wellness-szolgáltatásokat figyelembe véve. A dokumentum kitér az alapfogalmak körül kialakult kezdeti, különösen az egészségügyi és a turisztikai vonatkozások között fennálló szemléletbeli eltérések miatt felmerülő vitákra. Már itt rámutattak a szerzők, hogy a szakma képviselői sem értenek egyet az egészségturizmus pontos tartalmával kapcsolatban, ezért megpróbálták a kapott - részben eltérő - vélemények alapján minél átfogóbban meghatározni azt.

Látható, hogy a 2000-es évek elsó felében publikált szakirodalom túlnyomó többsége csak arra vállalkozott, hogy a legalapvetőbb fogalmakat határozza meg, a korábban kidolgozott meghatározásokat megerősítve vagy kiegészítve. A spa kifejezést többnyire szintén ide sorolták, bár még nem tettek kísérletet annak rendszerszerú elhelyezésére. Csupán arról van szó, hogy az egészségturizmus három fő fogalma mellett szükségesnek látták a spa-val kapcsolatos fogalmi kérdések körüljárását. A vendégforgalom növekedésével a termék a figyelem középpontjába került. A Széchenyi Terv

$\overline{{ }^{6} 74 / 1999 .(X I I .25 .)}$ EüM rendelet a természetes gyógytényezőkről. 
fejlesztéseinek hatékonyságát vizsgáló jelentés ${ }^{7}$ alapos helyzetértékelést közölt, azonban szakmailag nem törekedett szabatosságra. Így keverednek a fogalmak, nem tisztázott az egészségturizmus egésze, de a turizmus és idegenforgalom kifejezéseket sem szinonimaként alkalmazzák.

$\mathrm{Az}$ évtized második felében újra lendületet kapott az egészségturizmus kutatása, főleg a vendégforgalom további dinamikus növekedése következtében. A termékcsoport tudományos megalapozására tett kísérletek szerzői között a gazdasági és az egészségügyi szakemberek mellett megjelentek a geográfusok is. HEGEDÚS (2006) az egészségturizmus keresleti trendjeit vizsgáló tanulmányában áttekintette az alapfogalmak történeti alakulását, melyben az országos marketingszervezet (MT Zrt.) meghatározásait használta az adott időpontra vonatkozóan. Hasonlóképpen, az egészségturizmus egyes aspektusainak vizsgálata közben több más szerző is fontosnak tartotta az alapfogalmak bemutatását (AMBRUS 2006, ROZSNYAI 2006, DOBA-ZSIGMOND 2013). FÓRIS-BÉRCZES (2006) szúkebben a wellness terminológiáját igyekezett körüljárni, elsődlegesen nyelvészeti nézőpontból.

$\mathrm{Az}$ ORSZÁGOS EGÉSZSÉGTURIZMUS FEJLESZTÉSI STRATÉGIA (2007) szintén a fogalom összetett voltára hívja fel a figyelmet. A gyógyturizmus és a wellnessturizmus mellett - melyeknek ekkorra már kialakult Magyarországon a kritériumrendszere - már foglalkozik az akkor még kibontakozóban lévő medical wellness-szel, hangsúlyozva, hogy ennek fogalomrendszerét a fő küldőpiacokhoz, tehát a német nyelvterületekhez kell igazítani. Ez a korai megállapítás ma is helytálló, és rámutat arra, hogy nem szerencsés az angolszász fogalomrendszerhez igazodnunk, különösen annak tudatában, hogy hazánkban nem az a terület képezi az egészségturizmus iránt megnyilvánuló kereslet lényegi részét. PRISZINGERPÉNZES (2009) nem a fogalmak pontos meghatározására törekedtek, sokkal inkább az alapvető fogalmak tágan értelmezett ismertetésére. Újszerú azonban, hogy megjelent a medical turizmus kifejezés is a tanulmányban.

Az ÚJ SZÉCHENYI TERVBEN (2011) kiemelt szerepet kapott az egészségturizmus és az egészségipar. A fejlesztési dokumentum egyrészt megkülönbözteti a természetes gyógytényezőkre, másrészt az orvosi szolgáltatásokra épülő egészségturizmust, új teret nyitva ezzel az utóbbi terület, az orvosi turizmus fejlődése előtt. Bár fejlesztési dokumentumról van szó, az anyag tudományos alapossággal értékeli az egészségturizmus helyze-

${ }^{7}$ https://asz.hu/storage/files/files/\%C3\%96sszes\%20jelent\%C3\%A9s/2005/ 0536j000.pdf tét és lehetőségeit. Ezzel egyidejúleg új lendületet kaptak a tudományos vizsgálatok is, melyek jelentôs része fontosnak tartotta, hogy foglalkozzon az egészségturizmus egyre bóvuulő fogalmi rendszerével. Ezek közül azonban csupán az UNWTO által kezdeményezett pontos és nemzetközileg egységes nevezéktan meghatározására irányuló kutatás során törekedtek a teljességre. Ellenben ez a kutatás - vélhetően a számos résztvevő közötti együttmúködés nehézségei miatt - mind a mai napig nem került publikálásra.

SMITH-PUCZKÓ (2008), illetve KINCSES és szerzőtársai (2009) nemzetközi kontextusba helyezve igyekeztek vizsgálni az egészségturizmust, egyúttal túlléptek az alapfogalmak meghatározásán, és rendszerbe foglalva határozták meg a termékcsoport alkotóelemeit. Ezen munkák hiányossága, hogy nem a hazai piac szempontjából legfontosabb német nyelvterületet vették alapul, hanem a magyar szolgáltatók számára alig releváns angolszász példák alapján tettek megállapításokat ${ }^{8}$.

A szakirodalmi előzmények ellenére az ORSZÁGOS EGÉSZSÉGTURISZTIKAI FEJLESZTÉSI STRATÉGIÁT (2007) fogalmi bázisnak tekintve SZIVA (2010) arra jutott, hogy nemzetközi szinten nincs konszenzus az egészségturizmus meghatározása tekintetében. MEZŐKOVÁCS (2010) az egészségügyi ellátórendszer oldaláról közelítette meg a turisztikai terméket. A szakmai oktatás szempontjából mérföldkőnek tekinthető felmérésen alapult a Magyar Egészségturizmus Marketing Egyesület munkaerő-piaci kutatása (RUSZINKO et al. 2009, RUSZINKÓ-VIZI 2010). Az egészségturizmus egyik legalaposabb szakirodalmi feltárását végezte el doktori értekezése készítése során MOLNÁR (2011). Emellett további PhD-disszertációk is érintették a fogalmi kereteket (SŐRÉS 2013, ÁRPÁSI 2014, SAVELLA 2017, ZSARNÓCZKY 2017).

AUBERT és szerzőtársai (2012) az egészségturizmus desztinációmenedzsment felóli megközelítése során a II. NEMZETI FEJLESZTÉSI TERVET (2007-2013) vették alapul. Időközben több, részben vagy egészben oktatási célokat szolgáló munka is született, melyek sok esetben részterületeket vizsgáló tanulmányok segítségével igyekeznek rávilágítani a termékcsoport jellegzetességeire (BUDAI 2002, AUBERT-CSAPÓ 2004, HOJCSKA-SZABÓ 2010, RÁTZ-MICHALKÓ 2011, HUSTINÉ BÉRES 2011, BOROS et al. 2011, BAKUCZ-TEGZES 2016,

${ }^{8}$ Jelen tanulmány kizárólag a magyar nyelvű fogalmak terén kívánja a megfelelően alátámasztott, mindenki által elfogadott meghatározásokat rendszerbe foglalni. Különösen a küldőpiacok eltérő szerepére, nem lenne szerencsés ezzel párhuzamosan más nyelvterületek fogalomhasználatával összevetni a hazai gyakorlatot. 
Múhely

LACZKÓ-BÁNHIDI 2015). FENYVESI (2010) a nevezéktant értékelte az egészségipari kapcsolódások fényében. VÁRHELYI (2011) és SÁNDOR (2011) egyaránt a nemzetközi egészségturisztikai trendeket vizsgálta, míg KÚTVÖLGYI (2017) a fogyasztói magatartást értékelte. Hasonlóképpen a legújabb trendeket értékelte IVANCSONÉ HORVATH és szerzótársai (2016) tanulmánya.

\subsection{EGÉSZSÉGTURIZMUS A FELSŐOKTATÁSBAN}

Idôvel egyre népszerúbb lett az egészségturizmus a felsőoktatásban is, ahol az egyes intézmények igyekeztek komplexen, az egész turisztikai termékre kiterjedően kezelni a képzéseket. Ebben volt élenjáró a Heller Farkas Főiskola, ahol az országban egyedülálló módon - felismerve a szakterület fontosságát, a benne rejlő lehetőségeket és perspektívát - már 2003-ban elindult az egészségturizmus szakirány ${ }^{9}$. Azóta az erósödő piaci igényeknek megfelelően több intézmény is erre az útra lépett (az Eszterházy Károly Egyetem: Eger és Gyöngyös; a Neumann János Egyetem: Szolnok; a Debreceni Tudományegyetem, a Pécsi Tudományegyetem, a Budapesti Gazdaságtudományi Egyetem ${ }^{10}$. A felsőoktatásban többnyire a turizmus-vendéglátás alapszakok keretében végzik az oktatómunkát, de akad példa az egészségtudományi képzésekben való megjelenésre is. Emellett szakirányú továbbképzések is elérhetőek, ezek azonban elsősorban az egészségtudomány területén. A képzések - a hallgatói létszámok alapján - indításuk óta népszerúek, a hallgatók is tisztában vannak a területben rejlő munkaerô-piaci lehetôségekkel.

\section{Javaslatok a fogalmak használatára}

Az egészségturizmus legtöbb területe még új szakmának mondható, jelentôs a fejlődés, sok az új fogalom, és igazán még semmi sem kristályosodott ki. Ebból adódik, hogy ahány cég, oktatási intézmény stb., annyiféle definíciót használnak. Az általunk egységes használatra javasolt fogalmak és meghatározások figyelembe veszik a szakmai közmegegyezést, azonban számos esetben jelentôs pontosításokat kellett végeznünk annak érdekében, hogy eloszlassuk a félreértéseket, valamint hozzájáruljunk a hiányos vagy hibás alkalmazás visszaszorításához.

A feltárt, a napi használatot érintő, ezért mind a szakmai munka, mind pedig az oktatás során fél-

\footnotetext{
${ }^{9}$ A föiskolán kialakított képzés az intézmények egyesülését és átalakulását követően jelenleg a Budapesti Metropolitan Egyetemen zajlik.

${ }^{10}$ Az egyes intézmények aktuális, 2018/19. évi tantervei és szóbeli tájékoztatása alapján
}

reértésekre okot adó problémák elkerülése érdekében az alábbi megoldásokat javasoljuk:

- Nem az angolszász, hanem a hazai használathoz sokkal közelebb álló német fogalomrendszerhez kell közelítenünk.

- Egyértelmúvé kell tenni, és be kell épülnie a használatba is, hogy a (gyógytényezókön alapuló) gyógyturizmusnak nem része az orvosi turizmus. Míg előbbi a természetes gyógytényezőkön alapul, utóbbi a kórházi-klinikai keretek között elvégzett orvosi beavatkozásokat - leggyakrabban mútétekhez kapcsolódó szolgáltatásokat és komolyabb diagnosztikai eljárásokat - foglalja magába. Tehát a gyógyturizmus nem egyenlő az orvosi turizmussal, amire a jelenleg hatályos jogszabályok és a piaci szereplők szolgáltató tevékenysége engednek következtetni.

- Legyen egységesen elfogadott terminológia! Erre az alábbiakban teszünk javaslatokat egészségügyi, turisztikai és közgazdasági szempontból egyaránt mérlegelve az egyes fogalmak által lefedni kívánt területeket.

Az alábbiakban ismertetjük az egészségturizmushoz tartozó alapvetô fogalmak meghatározásait. Ahogy azt már láthattuk, a gyógyturizmus az a terület, amelynek elemei jogszabályi szinten kerültek definiálásra.

Az egészségturizmus az egészségi állapot fenntartása, illetve annak javítása érdekében történó utazást és az azzal kapcsolatban igénybe vett szolgáltatások összességét jelenti. Részei, a jelenlét/ beavatkozás intenzitása fokozódásának sorrendjében: a wellnessturizmus, a gyógyturizmus és az orvosi (egészségügyi) turizmus.

\subsection{WELLNESSTURIZMUS}

A wellnessturizmus a jó egészségi állapot fenntartását célozza utazással egybekötve, a holisztikus szemlélet jegyében testi, lelki, szellemi egészségre, ökológiai és társadalmi egyensúlyra törekedve. Az igazán jó wellnessprogram egyszerre jelent sikert az egészségmegőrzés és élményt az utazás szempontjából. Wellnessen belül az alábbi specializált termékeket különböztetjük meg:

Fitness: olyan életmódot és az ahhoz tartozó egyes tevékenységeket jelenti, melynek elemei a jó fizikai erőnlét, az egészséges életmód és az esztétikus külső. Mivel alapvetően sportos időtöltést jelent, inkább a fiatalabb és a középkorosztálynak szól.

Aktív wellness: a fitness-szel rokon fogalom, olyan wellnessprogram, mely előtérbe helyezi a - lehetôleg szabad téren végzett - rendszeres testmozgást 
a mai mozgásszegény életmódra adott válaszként. Célja, hogy a mindennapi munkából adódó túlzott stresszt vagy túlzott monotóniát a megfeleló sporttevékenységeken keresztül visszaszorítsa.

Családi wellness: az egész család számára tartalmas kikapcsolódást nyújtó relaxációs tevékenység, mely során a gyermekek szórakoztatása mellett a szülók is pihennek, számukra megfeleló wellnessprogramokon vehetnek részt.

Beauty: szépészeti kezeléseket, programokat jelent, ahol jellemzőek az arc-, kéz-, láb- és testkezelések. Amennyiben plasztikai sebészeti beavatkozás történik, és utazással kötik egybe, úgy az orvosi turizmushoz sorolandó.

Selfness: olyan életforma, mely alapvetóen önmagunk megismerésére helyezi a hangsúlyt. Követói a test és a lélek tökéletes összhangjára, és egy egészséges énkép kialakítására törekszenek. Saját képességeink felmérése gyakran a változtatás igényét is magával hozza, ezért a selfness lényeges eleme az önmegváltoztatás, önfejlesztés. Fó célja a magabiztosabb, optimistább és kiegyensúlyozottabb életvitel.

Soulness: míg a wellness döntően a testi rekreációra koncentrál (például sport, étkezés, masszázs), addig a soulness a szellemi-lelki regenerálódás erósítését, eszköztárának tudatos alkalmazását helyezi a középpontba. Célja a szellemi-lelki harmónia, a felfrissülés és feltöltődés, az érzelmi kifejezóképesség, a stabilitás és megújulás eszköztárának elsajátítása.

Medical wellness: wellness-szolgáltatások igénybe vétele orvosi felügyelettel és programozottsággal. Orvosi kivizsgáláson és ellenőrzésen alapul, célja a tudatos egészségmegőrzés. Mentális, emocionális, szociális, testi szakértelem jellemzi, a kiemelkedó szaktudás személyreszabott, speciálisan vendégközpontú ellátással párosul.

Értelmezésként meg kell jegyezni, hogy a fenti meghatározásokban a program és az életmód között van némi átfedés, mivel aki utazáson vesz részt, és a fent meghatározott szolgáltatásokat veszi igénybe, az egy „program”-on vesz részt, ellenben aki készség szinten sajátította el ezek alkalmazását, annak az adott wellnessprogram az „életmód"-jává vált.

\subsection{GYÓGYTURIZMUS}

A gyógyturizmus gyógyüdülóhelyeken vagy gyógyászati létesítményekben történő - meghatáro- zott minimális idejứ11 - tartózkodás, mely orvosi gyógymódok alkalmazásához kötött. Központi szerep jut valamilyen természetes gyógytényezőnek.

Gyógyhely: egy természetes gyógytényezővel rendelkezó településnek az a - hatóság által ellenôrzött és minôsített - része, ahol a természetes gyógytényezó igénybevételének gyógyintézményi feltételei (gyógyfürdő, gyógyszálló) biztosítottak, továbbá a gyógyítás zavartalanságát és a betegek nyugalmát biztosító környezeti feltételek (kiemelten védett területre előírt levegőtisztaság, fokozottan védett területnek megfeleló zajszint, rendezett zöldterületek stb.) adottak, valamint biztosított a pihenés infrastruktúrájának (közmúvek, közlekedés, hírközlés, kommunális szolgáltatások, ellátó-, szolgáltató intézmények stb.) kiépítettsége.

Természetes gyógytényezó: olyan természetes eredetú tényezố, amely tudományosan bizonyított módon kedvezó hatást fejt ki egy gyógykezelés során. Ilyen például a gyógyvíz, az elismert ásványvíz, a nem minősített ásványvíz, a hévíz, a gyógyiszap, az éghajlat, a barlangi klíma és a talajból nyert gázelőfordulások (például a tömény széndioxid-tartalmú mofetta). A természetes gyógytényezô gyógyhatása akkor tekinthetô bizonyítottnak, ha feltételezett hatását tudományosan elismert módszerek szerint lefolytatott orvosi megfigyelések megfelelően dokumentált és kiértékelt eredményei igazolják.

Gyógyfürdô és klímagyógyintézet (összefoglalóan): azok a létesítmények, amelyek fóként természetes gyógytényező felhasználásával folytatnak gyógyító vagy rehabilitációs tevékenységet. Az intézmény gyógyászati jellegére utaló elnevezéssel akkor múködtethetôk, ha - az üzemeltetéshez egyéb jogszabályokban előírt hatósági engedélyeken kívül - e megnevezés használatát a fenntartó vagy az üzemeltető kérelmére engedélyezi az Országos Gyógyhelyi és Gyógyfürdőügyi Fớigazgatóság.

Gyógyfürdô: az a létesítmény, amely gyógyvíz, gyógyiszap vagy egyéb természetes gyógytényezô (például gázelőfordulás) felhasználásával fürdőkezelést (balneoterápiát) nyújt, vagy elismert ásványvíz, hévíz, illetôleg melegített közmúhálózati víz felhasználásával végzett hidroterápiás kezelések mellett, egyéb fizikai gyógymódok alkalmazásával együtt, teljes körú fizioterápiás ellátást nyújt.

\footnotetext{
${ }^{11}$ Döntően krónikus, tehát egy-két nap alatt nem javuló betegségek kezelé-
} séről van szó, ezért szükséges a két-három hetes kúra. 
Éghajlati gyógyintézet (klimagyógyintézet): az a létesítmény, amely a helyi földrajzi adottságokból eredő sajátos éghajlati tényezők (a levegő tisztasága, hőmérséklete, páratartalma, a napfény stb.) felhasználásával nyúit gyógyító és rehabilitációs kezelést.

Mozgásszervi betegeket ellátó nappali kórház: az a létesítmény, mely járóbeteg-ellátás keretében teljes körú fizioterápiás ellátást nyújt kórházi körülmények között, a betegek napközbeni bent tartózkodásával, főként természetes gyógytényező alkalmazásával.

Gyógyfürdőkórház: a nem közvetlenül területi betegellátást nyújtó fekvőbeteg-gyógyintézet, amely a meghatározott betegségben szenvedők gyógyítását főként természetes gyógytényezők alkalmazásával végzi. A gyógyfürdőkórház járóbetegrészleggel is rendelkezhet.

Szanatórium: az a fekvőbeteg-gyógyintézet, amely más egészségügyi intézményben kivizsgált, illetôleg előzőleg már gyógykezelt betegek számára gyógyszeres, pszichoterápiás, vagy természetes gyógytényezón alapuló eljárással, illetve ezek együttes alkalmazásával nyújt fekvőbeteg-ellátást.

Gyógyüdülő: az a létesítmény, amely üdülés keretében teszi lehetôvé a jogosultak részére a természetes gyógymódok orvosi felügyelet melletti igénybevételét - saját gyógyászati részlegén vagy más gyógyintézmény kiegészítő szolgáltatásainak használatával.

Gyógyszálló: az a kereskedelmi szálláshely, amely főként természetes gyógytényező alkalmazásával saját gyógyászati részlegén önálló, vagy más gyógyintézet kiegészítő szolgáltatásainak bevonásával, orvosi ellenőrzés mellett terápiás lehetőséget biztosít vendégei számára.

Gyógyvíz-ivócsarnok: gyógyvizet szolgáltat közvetlenül a fogyasztók részére a helyszínen történó (kúraszerû) fogyasztás céljából.

Gyógybarlang (barlangterápiás intézet): megfelelően kialakított és berendezett természetes barlangképződmény vagy más, felszín alatti térség (bánya, táró), mely bizonyítottan gyógyhatású különleges légköri viszonyait használja fel egyes betegségek kezelésére. A létesítményhez funkcionálisan kapcsolódik egy a betegek elszállásolására alkalmas felszíni épület is, azonban a kezelés járóbeteg-ellátás keretében is igénybe vehetô.

\subsection{ORVOSI TURIZMUS}

Az orvosi turizmus orvosi kezelés, beavatkozás, diagnosztikai eljárás kedvéért történő - döntően külföldi utazás. Motivációi:

• jó minőségú ellátás (a küldőországénál) jóval kedvezóbb áron;

- orvosi ellátáshoz való azonnali hozzáférés, várólista nélkül;

- innovatív kezelések, eszközök, speciális tudás, melyek az adott küldőországban nem érhetőek el;

- a küldőországénál kedvezőbb jogszabályi feltételek.

Összegezve, az egészségturizmuson belül külön kategóriaként kell tekinteni a wellness-, a gyógyés az orvosi turizmusra (1. ábra). A fogalmak meghatározására, illetve ezen meghatározások pontosítására a fentiekben tettünk kísérletet. Ezen törekvésünkhöz leginkább a releváns hazai szakmai szervezet által használt, bevett meghatározást vettük alapul.

\section{Az egészségturizmus korszerú felosztása}

\begin{tabular}{|c|cc|}
\hline \multicolumn{3}{|c|}{ EGÉSZSÉGTURIZMUS } \\
\hline \multirow{2}{*}{ WELLNESSTURIZMUS } & GYÓGYTURIZMUS & ORVOSI TURIZMUS \\
Fitness & Gyógyfürdón & Fogászat \\
Aktív wellness & Gyógybarlang & Plasztikai segészet \\
Családi wellness & Gyógyiszap & Ortopéd sebészet \\
Selfness & Gyógyklima & Diagnosztika \\
Soulness & Mofetta & Rehabilitáció \\
Medical wellness & Ivókúra & \\
& &
\end{tabular}

* Hazánkban ezek a legjellemzóbb, külföldiek által igénybe vett orvosi szolgáltatások

Forrás: saját szerkesztés

\section{Következtetések}

Annak ellenére, hogy számos tanulmány foglalkozott az egészségturizmust érintő alapfogalmak meghatározásával, erre a feladatra még kevesen vállalkoztak megfelelő körültekintéssel. Eközben az alapproblémák között említhetjük, hogy - finoman fogalmazva - sok esetben nem pontos a fogalomhasználat. Különösen gyakori, hogy az orvosi turizmust nevezik „az igazi egészségturizmus"-nak, holott mindkét fogalom megfelelően lehatárolható, eltérő tartalommal rendelkezik. Egyetlen szakmának sem tesz jót, és

\footnotetext{
${ }^{12}$ Az egészségügyi vagy klinikai turizmus név is használatos. A nemzetközileg elfogadott medical tourism kifejezés leghüebb fordítása azonban az orvosi turizmus.
} 
nem segíti az abban dolgozók eredményességét, ha nem értik, ezáltal nem pontosan használják a szakmai alapfogalmakat. Ennek alapfeltétele, hogy már az oktatásban is egységes terminológia kerüljön alkalmazásra. Mivel az egészségturizmusban használatos fogalmakat mind a gazdaságtudomány, mind a földrajztudomány, mind az egészségtudomány szakemberei rendszeresen használják, meg kell ismerni, illetve el kell fogadni a másik szakmában (más szakmákban) dolgozók gondolkodását és terminológiáját. A fokozatosan globalizálódó turisztikai versenyben a szolgáltatók nem nélkülözhetik a marketingkommunikációt, amelynek sikere nagymértékben függ attól, hogy a piacon világos és egyértelmúen besorolható termékek és turisztikai fogadóterületek vannak-e jelen. Ez azért is fontos, mert ahhoz, hogy egy desztinációt, egy turisztikai terméket a potenciális turisták a vásárlói döntésben egyáltalán figyelembe vegyenek, mindenképpen egy jól felismerhetó, világos hasznot (élményt, vonzerőt) ígérő terméket bemutató marketingkommunikációra van szükség. Ezen túl azonban az is elengedhetetlen, hogy a leendő vendég pontosan értse a szolgáltató által a marketingkommunikációban használt terminológiát (HORKAY 2003).

A totális turizmus idôszakában az utazók mindenhol megjelennek, nem csak a számukra eredetileg létrehozott létesítményekben. Ehhez hasonló folyamat az egészségturizmusban már korábban is megfigyelhető volt, hiszen a gyógyvíz (illetve más gyógytényezók) alkalmazása elsődlegesen egészségügyi célokat szolgált. Turisztikai vonatkozása kezdetben csupán amiatt keletkezett, hogy ezek a gyógytényezők térben korlátozottan állnak rendelkezésre, tehát a gyógyulni vágyók részéről utazási kényszer lépett fel. Napjainkban azonban részben megfordult a helyzet, és maga az utazás lett az elsődleges cél, a desztinációban azonban minden adottság, jelenség az érdeklődés tárgyává vált. Így már nemcsak maga a gyógyvíz jelent vonzerôt a turisták számára, hanem a már meglévô (tágan értelmezett) egészségügyi infrastruktúra minden más eleme is, így a kozmetikai beavatkozások, speciális orvosi kezelések, vagy a szellemi rekreáció különböző formái. A fogalmak megfelelő, egységes alkalmazása nagyban elősegíti, hogy a különböző szakterületek hatékonyan tudjanak együttmúködni a turizmus alapinfrastruktúráját múköötetőkkel, és minél teljesebb körben ki tudják szolgálni a továbbra is gyorsan növekvő, részben a turisták, részben a leendó szakemberek részéről mutatkozó igényeket.

\section{Felhasznált irodalom}

AMBRUS T. (2006): A gyógyturizmus alapját képezô természeti és társadalmi tényezók vizsgálata Székelyföldön. In: Aubert A. (szerk.): Fejlesztés és képzés a turizmusban. II. Országos Turisztikai Konferencia tudományos közleményei. PTE TTK Földrajztudományi Intézet, Pécs. CD kiadvány. pp. 168-178.

ÁRPÁSI Z. (2014): Wellness turisztikai szolgáltatások fejlesztésének lehetôségei a dél-alföldi régióban. Doktori (PhD) értekezés. Szent István Egyetem, Gazdálkodás-és Szervezéstudományok Doktori Iskola, Gödölló.

AUBERT A. - BERKI M. (2007): A nemzetközi és a hazai turizmus területi folyamatai, piaci tendenciái a globalizáció korában. Földrajzi Közlemények. 55(3). pp. 119-131.

AUBERT A. - CSAPÓ J. (2004): Egészségturizmus. Bornus Nyomda, Pécs.

AUBERT A. - JÓNÁS-BERKI M. - MARTON G. (2012): Az egészségturizmus térszervezési és menedzselési sajátosságai Magyarországon. In: Nyári D. (szerk.): Kockázat - Konfliktus Kihívás. A VI. Magyar Földrajzi Konferencia, a MERIEXWA Nyitókonferencia és a Geográfus Doktoranduszok Országos Konferenciájának Tanulmánykötete. Szegedi Tudományegyetem, Természeti Földrajzi és Geoinformatikai Tanszék, Szeged. pp. 13-21.

BAKUCZ M. - TEGZES A. (szerk.) (2016): Fürdôtelepülések versenyképességi vizsgálata néhány magyar és közép-európai régióban. Pécsi Tudományegyetem, Pécs.

BUDAI Z. - SZEKÁCS O. (2001): A magyar egészségturisztikai kínálat alakítása a különböző célcsoportok igényei szerint. Turizmus Bulletin. 5(4). pp. 3-6.

BUDAI Z. (2002): Marketing a fürdőfejlesztésben. Turizmus Bulletin. 6(1). pp. 3-5.

DOBA SZ. -ZSIGMOND E. (2013): Gyógy?Wellness? Spa?- Terminológiai útvesztô az egészségturizmusban. Ekonomické štúdie - teória a prax. International Research Institute, Komárno. pp. 466-474.

FENYVESI J. (2010): Egészségturizmus és egészségipar. Magyar orvosi nyelv. 10(2). pp. 59-60.

FÓRIS Á. - BERCZES E. (2006): A wellness terminológiája. Magyar nyelvốr. 130(4). pp. 399-413.

GONDOS B. (2012): Az egészségturizmus és az életminőség kapcsolata: Az egészségturizmus és az életminőség megjelenése a nemzetközi és hazai fejlesztési koncepciókban, stratégiákban. In: Lőrincz I. (szerk.): A gazdasági és társadalmi átalakulás perspektívái Magyarországon. XV. Apáczai-napok 2011, Nemzetközi Tudományos 
Konferencia. Nyugat-magyarországi Egyetem Apáczai Csere János Kar, Győr. Tanulmánykötet. pp. 8-15.

HEGEDÛS V. (2006): Az egészségturizmus fogalmi rendszerének és keresletének változásai Magyarországon. Földrajzi Értesító. 55(3-4). pp. 355-373.

HOJCSKA Á. E. - SZABÓ Z. (2010): Fizioterápia az egészségturizmusban. Oktatási segédlet. Szent István Egyetem Egészségtudományi és Környezetegészségügyi Intézet, Gyula.

HORKAY N. (2003): Turisztikai márka és márkapolitika a desztináció-menedzsmentben I. Turizmus Bulletin. 7(1). pp. 47-53.

HORKAY N. (2003): Turisztikai márka és márkapolitika a desztináció-menedzsmentben II. Turizmus Bulletin. 7(2). pp. 21-30.

KINCSES GY - BORBÁS I. - MIHALICZA P. VARGA E. - UDVARDY E. (2009): A gyógyturizmus tendenciái a világban. Egészségügyi Gazdasági Szemle. 2009/5. pp. 33-37.

KÚTVÖLGYI V. (2017): Az egészségturizmus fogyasztásszociológiai szempontú megközelítése. Acta Carolus Robertus. 7(1). pp. 173-188.

LACZKÓ T. - BÁNHIDI M. (2015): Sport és egészségturizmus alapjai. Pécsi Tudományegyetem Egészségtudományi Kar, Pécs.

MÁLOVICS J. - MÁLOVICS É. (2009): Szervezeti kultúra és kompetenciák az egészségturizmusban: elméleti modellek és empirikus kutatási lehetőségek In: Hentesi E. Majó Z. - Lukovics M. (szerk.): A szolgáltatások világa. JATEPress, Szeged. pp. 108-126.

MEZŐ F. - KOVÁCS T. (2010): Az egészségturizmus mint az Észak-alföldi régió lehetséges kitörési pontja. Turizmus Bulletin. 14(4). pp. 10-18.

MICHALKÓ G. - RÁTZ T. (2003): A sátorverésen túl. A turizmustudomány magyarországi állapotairól. Magyar Tudomány. 48(6). pp. 447-457.

MOLNÁR CS. (2011): Az egészségturisztikai fejlesztések hatásai, különös tekintettel KeletMagyarországra. Doktori (PhD) értekezés. Széchenyi István Egyetem, Regionális- és Gazdaságtudományi Doktori Iskola, Győr.

PRISZINGER K. - PÉNZES E. (2009): Fogyasztói magatartás a termálvízre alapozott turisztikai szolgáltatások tekintetében. A Miskolci Egyetem Közleménye. A-sorozat, Bányászat. 77. pp. 141150.

RÁTZ T. - MICHALKÓ G. (2011): Destineering és IVF kezelés - trendek a globális egészségturizmusban In: Michalkó G. - Rátz T. (szerk.): Egészségturizmus és életminôség Magyarországon: Fejezetek az egészség, az utazás és a jól(l)ét magyarországiösszefüggéseiről. MTA Földrajztudományi Kutatóintézet, Budapest. pp. 13-26.
RÁTZ T. (2001): Zennis és Lomi Lomi, avagy Új trendek az egészségturizmusban. Turizmus Bulletin. 5(4). pp. 7-16.

ROZSNYAI K. (2006): A teremtő gondolat ereje. Piacformáló egészségturisztikai képzés a Gyulai Fóiskolán. In: Aubert A. (szerk.): Fejlesztés és képzés a turizmusban. II. Országos Turisztikai Konferencia tudományos közleményei. PTE TTK Földrajztudományi Intézet, Pécs. CD kiadvány. pp. 54-58.

RUSZINKÓ Á. - DONKA A. (2015): Fürdők jövedelmezőségének összehasonlító elemzése. In: Galambos I. - Michalkó G. - Törzsök A. - Wirth G. (szerk.): Fürdővárosok. Történelmi Ismeretterjesztő Társulat Egyesület és Magyar Földrajzi Társaság, Budapest. pp. 263-274.

RUSZINKÓ Á. - VIZI I. (2011): Az egészségturisztikai munkaerőpiac helyzete. Turizmus Bulletin. 14(4). pp. 44-52.

SÁNDOR R. (2011): Egészségturizmus innováció megjelenése és területi összehasonlítása a németajkú és mediterrán országok viszonylatában. Mikes International. 11(1). pp. 49-55.

SAVELLA O. (2017): Informális tanulás egészségmagatartás-formáló hatása az egészségturizmusban. Doktori (PhD) értekezés. Eszterházy Károly Egyetem, Neveléstudományi Doktori Iskola, Eger.

SŐRES A. (2013): Az egészségturizmus hatása az életminôségre Hajdúszoboszlón. Doktori (PhD) értekezés. Debreceni Egyetem, Ihrig Károly Gazdálkodás- és Szervezéstudományok Doktori Iskola, Debrecen.

SMITH, M. - PUCZKÓ L. (2008): Egészségturizmus: gyógyászat, wellness, holiszitika. Akadémiai Kiadó, Budapest.

SZABÓ Z. (2011): A magyar gyógyfürdőturizmus és a piac. In: Lőrincz I. (szerk.): A gazdasági és társadalmi átalakulás perspektívái Magyarországon. XV. Apáczai-napok 2011, Nemzetközi Tudományos Konferencia. Nyugatmagyarországi Egyetem Apáczai Csere János Kar, Győr. Tanulmánykötet. pp. 54-61.

SZIVA I. (2010): Öntsünk tiszta vizet... Az egészségturizmus fogalmi lehatárolása és trendjeinek válogatott bibliográfiája. Turizmus Bulletin. 14(4). pp. 73-76.

VAJDA R. - VADAS V. (1990): Magyarország gyógy-idegenforgalma. Alfaprint Nyomdaipari Kisszövetkezet, Budapest.

VÁRHELYI T. (2012): Világtrendek az egészségturizmusban - a sikeres szolgáltatók földrajzi eloszlásának változásai. In: Nyári (szerk.): Kockázat - Konfliktus - Kihívás. A VI. Magyar Földrajzi Konferencia, a MERIEXWA Nyitókonferencia és a Geográfus Doktoranduszok Országos 
Konferenciájának Tanulmánykötete. Szegedi Tudományegyetem Természeti Földrajzi és Geoinformatikai Tanszék, Szeged. pp. 941-948.

ZSARNÓCZKY M. B. (2017): Az egészségturizmus folyamatainak vizsgálata észak-magyarországi mintaterületeken. Doktori (PhD) értekezés. Szent István Egyetem, Enyedi György Regionális Tudományok Doktori Iskola, Gödöllő.

\section{Internetes források}

\section{AZ EGÉSZSÉGTURIZMUS MARKETING-} KONCEPCIÓJA (2002): https://mtu.gov.hu/documents/prod/93_egtur_marketing_koncepcio.pdf, Letöltve: 2019. június 6.

BOROS SZ. - PRINTZ-MARKÓ E. PRISZINGER K. (2011): Egészségturizmus. In: Michalkó G. (szerk.): Turisztikai terméktervezés és fejlesztés. http://www.eturizmus. pte.hu/szakmai-anyagok/Turisztikai\%20term\%C3\%A9ktervez\%C3\%A9s\%20\%C3\%A9s\%20 fejleszt\%C3\%A9s/book.html, Letöltve: 2019. június 6.

EGÉSZSÉGTUDOMÁNYI FOGALOMTÁR. https://fogalomtar.aeek.hu/index.php/ Kezd\%C5\%91lap, Letöltve: 2018. január 1.

HUSTINÉ BÉRES K. (2011): Fürdők és az egészségturizmus közgazdaságtana. Elektronikus jegyzet, Széchenyi István Egyetem. http:// www.tankonyvtar.hu/hu/tartalom/tamop412A/2010-0019_Furdok_es_az_egeszsegturizmus_kozgazdasagtana/index.html, Letöltve: 2019. június 6.
IVANCSÓNÉ HORVÁTH ZS. - PRINTZ-MARKÓ E. - DARABOS F. (2016): Wellness generációk - Generációk a wellnessben. Kautz Gyula Konferencia, Nyugat-magyarországi Egyetem Apáczai Csere János Kar. Konferenciakötet. https://kgk.sze.hu/images/dokumentumok/ kautzkiadvany2016/Ivancsone_PrintzMarkoE_ DarabosF.pdf, Letöltve: 2019. június 6.

NTS (NEMZETI TURIZMUSFEJLESZTÉSI STRATÉGIA) (2017): https://www.kormany. $\mathrm{hu} /$ download/8/19/31000/mtu_kiadvany_ EPUB_297x210mm\%20-\%20preview.pdf, Letöltve: 2019. június 6.

ORSZÁGOS EGÉSZSÉGTURIZMUS FEJLESZTÉSI STRATÉGIA (2007): http s://2010-2014.kormany.hu/downlo$\mathrm{ad} / \mathrm{b} / 8 \mathrm{e} / 20000 /$ Egeszsegturizmusstrategia. pdf\#!DocumentBrow, Letöltve: 2019. június 6.

RUSZINKÓ Á. - KÔVÁRI I. - MEZÓSI CS. SZALAI E. - SZÓKE T. - VERMESI A. - VIZI I. - VÖRÖS I. (2009): Egészségturisztikai munkaerô-piaci kutatás. Magyar Egészségturizmus Marketing Egyesület, Budapest. http://www. meme.hu/memedok/egesszegturisztikai_munkaero-piaci_kutatas_2009.pdf, Letöltve: 2019. június 6.

ÚJ SZÉCHENYI TERV (2011): http://www.terport. hu/webfm_send/535, Letöltve: 2019. június 6.

II. NEMZETI FEJLESZTÉSI TERV (2007-2013): http://www.terport.hu/teruletfejlesztes/orszagos-szint/fejlesztesi-dokumentumok/ii-nemzeti-fejlesztesi-terv-uj-magyarorsza, Letöltve: 2019. június 6 . 